\title{
Use of a tourniquet in patients with sickle-cell disease
}

\author{
Y. Adu-Gyamfi fFarCs, ${ }^{*}$ M. Sankarankutty FRCs, $\dagger$ \\ S. Marwa Ms $\dagger$
}

Fifteen patients, 13 male and two female, known to be carrying the sickle-cell gene (12 HbSS and $3 \mathrm{HbAS}$ ), who were undergoing operations requiring a bloodless field, were included in the study. Of the 12 with $H b S S$, seven had haemoglobin $A_{1}$ component of between 11 and $27 \%$, three had fetal haemoglobin ranging from 5.7 to $29 \%$ and the remaining two had increased haemoglobin $A_{2}$ concentrations suggesting a beta non-thalassaemia combination. All had a tourniquet applied to the appropriate limb and were given general anaesthesia with moderate hyperventilation throughout the procedure. The tourniquet inflation time was $61.7 \pm 27.5 \mathrm{~min}$. The mean $\mathrm{PaO}_{2}$ remained above $200 \mathrm{mmHg}$, mean $\mathrm{PaCO}_{2}$ was less than 37 $\mathrm{mmHg}$, and $\mathrm{pH}$ ranged between 7.40 and 7.45. There were no clinically important changes in BP or ECG. All patients made uneventful recoveries and none developed sickle-cell crises. It is suggested that it is safe to use tourniquet in patients with sickle-cell disease provided optimum acid-base status and oxygenation are maintained throughout the procedure.

Quinze patients dont 13 hommes et 2 femmes, connus porteurs du gène d'hématie falciforme (12 HbSS et $3 \mathrm{HbAS}$ ) ont été inclus dans l'étude. Ils subissaient des interventions nécessitant un champ exsangue. Parmi les $12 \mathrm{HbSS}$, sept avaient une $H b A_{l}$ entre 11 et $27 \%$, trois avaient une $\mathrm{Hb}$ foetale entre 5,7 et $29 \%$ et deux autres avaient une $\mathrm{Hb}_{2}$ accrue suggérant une combinaision $\beta$ non thalassémique. Tous ont eu un garrot

\section{Key words}

BLOOD: sickle-cell disease;

COMPLICATIONS: sickle-cell disease;

EQUIPMENT: tourniquets.

From the Departments of Anaesthesiology* and

Orthopaedics, $\dagger$ King Faisal University, College of Medicine,

Dammam, Saudi Arabia.

Address correspondence to: Dr. Y. Adu-Gyamfi, Department of Anaesthesiology, King Fahd Teaching Hospital, P.O. Box 40045, Al-Khobar 31952, Saudi Arabia.

Accepted for publication 29th April, 1992. placé sur le membre approprié et ont eu une anesthésie générale avec une hyperventilation modérée pendant l'intervention. Le temps de garrot a été de 61,7 $\pm 27,5 \mathrm{~min} . \mathrm{La} \mathrm{PaO}_{2}$ moyenne est restée au-dessus de $200 \mathrm{~mm}$ de $\mathrm{Hg}$ la $\mathrm{PCO}_{2}$ moyenne inférieure à $37 \mathrm{mmHg}$ et le pH entre 7,40 et 7,45. Il n'y a pas eu de changement cliniquement important de la pression artérielle et de l'ECG. Tous les patients se sont réveillés sans problème, aucun n'a eu de crise d'hémolyse. On suggère qu'll est inoffensif d'utiliser un garrot en cas de thalassodrépanocytose pourvu que l'état acido-basique et l'oxygénation optimum soient maintenus pendant lintervention.

The use of a tourniquet to provide a bloodless field during surgery is generally discouraged in patients who carry the sickle-cell gene ${ }^{1,2}$ because it may lead to circulatory stasis, acidosis, and hypoxaemia; the triad of clinical conditions known to induce sickling. However, the literature shows no clear contraindication to the use of a tourniquet in such patients. ${ }^{3-5}$

In the Eastern Province of Saudi Arabia 15-27\% of the population carry the sickle-cell gene ${ }^{6}$ with nearly $2 \%$ SS homozygotes. ${ }^{7,8}$ Sickle-cell disease in this area is reported to have a relatively benign clinical course attributable to a high level of fetal haemoglobin. But it is increasingly recognised that there is much variability in the clinical expression of the disease in this region. Considerable morbidity, including extremely painful crises and osteomylitis, ${ }^{9-12}$ has been observed. These and other surgical conditions of the limbs may sometimes require a bloodless field for operation.

Therefore, this study was undertaken in this environment in order to determine whether the use of a tourniquet is harmful to patients carrying the sickle-cell gene.

\section{Methods}

Patients carrying the sickle-cell gene who were undergoing surgery on a limb requiring a bloodless field were included in the study. They received premedication with diazepam $0.15 \mathrm{mg} \cdot \mathrm{kg}^{-1}$ po one and half hours before operation. After establishing an $i v$ line for hydration during operation, the patients were pre-oxygenated for two minutes before induction of anaesthesia. Intraoperative monitoring included ECG, blood pressure, pulse rate, 
end-tidal carbon dioxide, and pulse oximetry. The induction sequence was as follows: fentanyl $2 \mu \mathrm{g} \cdot \mathrm{kg}^{-1}$, atracurium $0.5 \mathrm{mg} \cdot \mathrm{kg}^{-1}$, thiopentone $5 \mathrm{mg} \cdot \mathrm{kg}^{-1}$, followed by tracheal intubation. Maintenance anaesthesia was with isoflurane $0.5-1 \%$, nitrous oxide $50 \%$ in oxygen, supplements of fentanyl and atracurium, and controlled mechanical ventilation which was adjusted to produce $\mathrm{PETCO}_{2}$ of $30-35 \mathrm{mmHg}$.

After settling the patient on mechanical ventilation, the radial artery was cannulated for arterial blood sampling. A bloodless field was established using an Esmarch bandage and the tourniquet inflated to $250 \mathrm{mmHg}$ for the upper limb, and $300 \mathrm{mmHg}$ for the lower limb. At the end of the operation, the inflation time was recorded before the tourniquet was deflated. Wound dressing and/ or plaster of paris was applied and the residual neuromuscular blockade was reversed with atropine and neostigmine.

Four sets of arterial blood samples were obtained from all patients as follows: after induction of anaesthesia but immediately preceding tourniquet application (control), $30 \mathrm{~min}$ after tourniquet inflation, one minute and one hour after tourniquet deflation. A venous sample was obtained with every arterial blood sample to determine the irreversibly sickled-cell count (ISC), which was defined as the number of irreversibly sickled cells per hundred red blood cells. Clinical end-points of pain were used to determine thrombotic episodes.

Haemoglobin genotypes HbSS and HbAS were defined as erythrocyte haemoglobin $\mathrm{S}$ contents of more than $70 \%$ and less than $40 \%$ respectively.

Analysis of the data was done with the SPSS/PC+ statistical package. The means were compared using Student's $t$ test for paired variables.

\section{Results}

There were 15 patients, 13 male and two female. The age range was from 12 to $35 \mathrm{yr}$ with a mean of 21.3 yr (I 8.0). The lowest haemoglobin concentration was 7 $\mathrm{g} \cdot \mathrm{dl}^{-1}$ and the highest was $13 \mathrm{~g} \cdot \mathrm{dl}^{-1}$. The haemoglobin genotype distribution was as follows: 12 SS and 3 AS. Of the $12 \mathrm{HbSS}$ cases, seven had haemoglobin $\mathrm{A}_{1}$ component of between 11 and $27 \%$, three fetal haemoglobin ranging from 5.7 to $29 \%$ and the remaining two had raised haemoglobin $A_{2}$ concentration suggesting a beta non-thalassaemia combination (Table I). All the $12 \mathrm{SS}$ patients had suffered painful crises and some had received multiple blood transfusions in the past. One of them (patient \#6) had had splenectomy. No clinically significant changes were observed in the arterial blood pressure and the ECG. The duration of tourniquet application ranged from 35 to 115 min (mean $61.7 \pm 27.5$ ).

Table II shows the perioperative changes in arterial blood gases and the irreversibly sickled-cell count. The mean $\mathrm{PaO}_{2}$ remained above $200 \mathrm{mmHg}$, mean $\mathrm{PaCO}_{2}$ was less than $37 \mathrm{mmHg}$ and the $\mathrm{pH}$ ranged between 7.40 and 7.45. Minimal change occurred between the pretourniquet $\mathrm{PaCO}_{2}$ and the $\mathrm{PaCO}_{2}$ one minute after tourniquet deflation $(P<0.05)$. Minimal differences also occurred in base excess which were of no clinical importance. The mean irreversibly sickled-cell count did not change. When the data were analysed separately for the 12 SS patients, the findings were the same. None of the patients developed sickle-cell crises and all made uneventful recovery.

\section{Discussion}

The local effects of two-hour tourniquet ischaemia in a human limb include progressive hypoxaemia, hypercarbia, lactic acid accumulation and consequent decrease in $\mathrm{pH} .{ }^{12}$ Systemic effects after tourniquet deflation are due to the uptake of the local products of anaerobic metabolism from the recently ischaemic limb into the general circulation. In vitro studies of the effects of deoxygenation on the sickle-cell show that progressive decrease in oxygen tension from $70 \mathrm{mmHg}$ to $25 \mathrm{mmHg}$ provokes reciprocal increase in sickling and that sickling of $5 \%$ of red cells occurs at a $\mathrm{PO}_{2}$ of $40 \mathrm{mmHg}$ and $90 \%$ at $\mathrm{PO}_{2}$ of 25 mmHg. ${ }^{13}$ These studies suggest that intravascular sickling during the use of a tourniquet in sickle-cell patients is a theoretical possibility. However, some retrospective studies have shown that no harmful effects occurred after the use of a tourniquet in patients with sickle-cell disease. ${ }^{3-5}$

There are many experimental and clinical reports of the systemic effects of tourniquet release in patients with normal haemoglobins. ${ }^{14-19}$ These suggest that the systemic effects are usually minimal, transient and of no clinical significance. Our results with the abnormal haemoglobin$\mathrm{S}$ patients confirmed this observation and we found no changes in blood gas results, except in the $\mathrm{PaCO}_{2}$ and base excess.

It has been suggested that since there may be an acute increase in $\mathrm{PaCO}_{2}$ after tourniquet deflation, a period of hyperventilation would expedite the return of $\mathrm{PaCO}_{2}$ and $\mathrm{pH}$ to normal levels. ${ }^{20}$ The administration of sodium bicarbonate prior to tourniquet release has also been advocated. ${ }^{15}$ In this study the patients were not given bicarbonate but their lungs were moderately hyperventilated until the end of anaesthesia. No clinically important changes were observed in the blood gases or in the irreversibly sickled-cell count which is an index of haemolysis in sickle cell disease. 21,22

We suggest that it is the chronicity and persistence, rather than the acuteness of changes in $\mathrm{PaO}_{2}$ and/or $\mathrm{pH}$ which precipitate the in vivo sickling process. Our find- 
TABLE I Clinical variables in 15 sickle-cell patients requiring bloodless field for various operations

\begin{tabular}{|c|c|c|c|c|c|c|c|c|c|c|}
\hline \multirow[b]{2}{*}{$S N$} & \multirow[b]{2}{*}{ Age } & \multirow[b]{2}{*}{$\operatorname{Sex}$} & \multirow[b]{2}{*}{$H b \cdot d l^{-I}$} & \multicolumn{4}{|c|}{ Electrophoresis \% } & \multirow{2}{*}{$\begin{array}{l}\text { Tourniquet } \\
\text { duration } \\
\text { (minutes) }\end{array}$} & \multirow[b]{2}{*}{ Diagnosis } & \multirow[b]{2}{*}{ Operation } \\
\hline & & & & $S$ & $A_{l}$ & $A_{2}$ & $F$ & & & \\
\hline 1 & 16 & $\mathbf{F}$ & 11.3 & $89^{*}$ & 11 & 0 & 0 & 50 & Acute osteomyelitis tibia & Drainage and biopsy \\
\hline 2 & 17 & M & 8.4 & $71^{*}$ & 0 & 0 & $29 \ddagger$ & 35 & Acute osteomyelitis tibia & Decompression and drainage \\
\hline 3 & 14 & $\mathbf{M}$ & 9.6 & $73^{*}$ & 27 & 0 & 0 & 40 & Acute osteomyelitis tibia & Drainage and biopsy \\
\hline 4 & 12 & $\mathbf{M}$ & 10.9 & $79 *$ & 21 & 0 & $\mathbf{0}$ & 65 & Septic arthritis knee & Drainage \\
\hline 5 & 23 & M & 12.3 & $82^{*}$ & 16 & 2 & 0 & 95 & Fracture dislocation ankle & Internal fixation \\
\hline 6 & 16 & M & 11.3 & $93^{*}$ & 0 & $7 \dagger$ & 0 & 30 & Acute osteomyelitis, tibia & Decompression \\
\hline 7 & 19 & $\mathbf{M}$ & 10.9 & $79^{*}$ & 21 & 0 & 0 & 105 & Fracture radius and ulna & Internal fixation \\
\hline 8 & 18 & $\mathbf{M}$ & 10.7 & 35 & 63 & 2 & 0 & 55 & Compound fracture, tibia & Debridement and POP \\
\hline 9 & 40 & $\mathbf{M}$ & 11.7 & 31 & 66 & 3 & 0 & 115 & Fracture shaft lower tibia & Internal fixation \\
\hline 10 & 28 & $\mathbf{M}$ & 7.8 & $90^{*}$ & 0 & $4.3 \dagger$ & $5.7 \ddagger$ & so & Acute osteomyelitis & Decompression and biopsy \\
\hline 11 & 30 & $\mathbf{M}$ & 13 & 38 & 59 & 3 & 0 & 45 & Acute osteomyelitis & Decompression and biopsy \\
\hline 12 & 17 & M & 9 & $81^{*}$ & 0 & 1 & $18 t$ & 45 & Acute osteomyelitis & Decompression and biopsy \\
\hline 13 & 14 & $\mathbf{F}$ & 11 & $88^{*}$ & 22 & 0 & 0 & 40 & Septic arthritis elbow & Drainage and biopsy \\
\hline 14 & 35 & $\mathbf{M}$ & 10.6 & $80^{*}$ & 0 & 0 & $20 \ddagger$ & 105 & Synovial hypertrophy knee & Synovectomy \\
\hline 15 & 20 & $\mathbf{M}$ & 11.6 & $76^{*}$ & 22 & 0 & 2 & 50 & Septic arthritis knee & Drainage \\
\hline
\end{tabular}

*Patients with SS genotype.

†SS patients with beta non-thalassaemia combination.

tSS patients with high fetal haemoglobin.

TABLE II Summary of changes in arterial blood gases and irreversibly sickled-cell count $(n=15)$

\begin{tabular}{|c|c|c|c|c|}
\hline Arterial blood gas & Pre-tourniquet & $\begin{array}{l}30 \text { min } \\
\text { afier tourniquet } \\
\text { application }\end{array}$ & $\begin{array}{l}I \mathrm{~min} \\
\text { afier release of } \\
\text { tourniquet }\end{array}$ & $\begin{array}{l}1 \mathrm{hr} \text { in } \\
\text { recovery room }\end{array}$ \\
\hline pH & $7.4 \pm 0.04$ & $7.44 \pm 0.05$ & $7.45 \pm 0.05$ & $7.42 \pm 0.04$ \\
\hline $\mathrm{PaCO}_{2}$ & $36.3 \pm 3.4^{*}$ & $33.7 \pm 6.8$ & $34.1 \pm 3.8^{*}$ & $37.6 \pm 6.1$ \\
\hline $\mathrm{HCO}_{3} \mathrm{mEq} \cdot \mathrm{L}^{-1}$ & $23 \pm 1.3$ & $22 \pm 4.5$ & $22 \pm 4.1$ & $23 \pm 3.1$ \\
\hline Base excess $\mathrm{mEq} \cdot \mathrm{L}^{-1}$ & $0.36 \pm 1.52$ & $-0.06 \pm 2.48$ & $-0.3 \pm 2.45$ & $-0.75 \pm 1.3$ \\
\hline $\mathrm{PaO}_{2} \mathrm{mmHg}$ & $225 \pm 79$ & $242 \pm 68$ & $211 \pm 56$ & $202 \pm 57$ \\
\hline $\mathrm{O}_{2}$ saturation $\%$ & $99.4 \pm 0.8$ & $99.6 \pm 0.6$ & $99.5 \pm 0.4$ & $99.4 \pm 0.8$ \\
\hline Irreversibly sickling count \% & $1.2 \pm 1.0$ & $2.5 \pm 2.0$ & $2.1 \pm 1.2$ & $1.8 \pm 1.6$ \\
\hline
\end{tabular}

$* P<0.05$.

ings confirm the experience of Stein and Urbaniak ${ }^{3}$ and we conclude that the use of a tourniquet in sickle-cell patients is not associated with harmful effects provided that optimum acid-base status and oxygenation are maintained throughout anaesthesia.

\section{Acknowledgements}

We wish to thank Professor A.M. Ahmed, Head of Department of Haematology and his staff, for all the facilities they provided for the study. We also wish to thank Professor Lade Wosornu of the Department of Surgery and Professor J.A.O. Magbagbeola of the Department of Anaesthesia for their interest and constructive criticisms in the preparation of the manuscript.

\section{References}

1 Woerlee GM. Sickle cell anaemia in: Common Perioperative Problems and the Anaesthetist, $1^{\text {st }}$ ed. Boston: Kluwer Academic publishers, 1988; 223-4.
2 Epps $C H$ Jr, Bryant DD III, Cole MJ, Castro $O$. Osteomyelitis in patients who have sickle-cell disease. Diagnosis and management. J Bone Joint Surg 1991, 73A (9): 1281-94.

3 Stein RE, Urbaniak $J$. Use of the tourniquet during surgery in patients with sickle-cell hemoglobinopathies. Clin Orthop 1980, 151: 231-3.

4 Gilbertson $A A$. Anaesthesia in West African patients with sickle-cell anaemia, haemoglobin $\mathrm{SC}$ disease, and sicklecell trait. Br J Anaesth 1965; 37: 614-22.

5 Martin WJ, Green $D R$, Dougherty $N$, Morgan $D$, $O$ 'Heir $D$, Zarro $M$. Tourniquet use in sickle-cell disease patients. J Am Podiatr Med Assoc 1984, 74: 6: 291-4.

6 El-Hazmi MAF. Haemoglobinopathies in Saudi Arabia. Saudi Med J 1989 10: $201-2$.

7 Lehman H, Maranjian G, Mourant AE. Distribution of sickle-cell haemoglobin in Saudi Arabia. Nature 1963; 198: 492-3. 
8 Gelpi AP. Sickle-cell disease in Saudi Arabia. Acta Haematol (Basel) 1970; 43: 89-99.

9 Al-Awamy BH, Wilson WA, Esmail SM, Abu-Nawarig $M$. Sickle-cell haemoglobinopathy and salmonella osteomyelitis in the eastern province of Saudi Arabia. Trop Geogr Med 1982; 34: 51-4.

10 Sadat A, Kutty $S$, Kutty $K$. Recent observations on osteomyelitis in sickle-cell disease. Int Orthop 1985; 9: 97-9.

11 Al-Awamy BH, Sumer T, Naeem MA, Al-Mouzan M. Pathological fracture of vertebral column in association with sickle cell anemia in Saudi Arabia. Trop Geogr Med 1986; 38: 421-4.

12 Wilgis EFS. Observations on the effects of tourniquet ischemia. J Bone Joint Surg 1971; 53A: 1343-6.

13 Harris JW. Studies in the destruction of old blood cells: the biophysics and biology of sickle-cell disease. Arch Intern Med 1956; 97: 145-68.

14 Miller SH, Lung RJ, Graham WP 3rd, Davis TS, Rusenas I. The acute effects of tourniquet ischemia on tissue and blood gas tensions in the primate limb. J Hand Surg 1978; 3: 1: 11-20.

15 Hassan H, Gjessing J, Tomlin PJ. Blood gas changes following tourniquet release during spinal anaesthesia. $\mathrm{Br} \mathbf{J}$ Anaesth 1978, 50: 76.

16 Modig J, Kolstad K, Wigren A. Systemic reactions to tourniquet ischaemia. Acta Anaesthesiol Scand 1978; 22: 609-14.

17 Klenerman $L$, Biswas $M$, Hulands GA, Rhodes $A$. Systemic and local effects of the application of a tourniquet. J Bone Joint Surg 1980; 62: 385-8.

18 Deen L, Nyst CLTM, Zuurmond WWA. Metabolic changes after tourniquet release. Acta Anaesthiol Belg 1982; 2: 107-13.

19 Lynn AM, Fischer T, Brandford HG, Pendergrass TW. Systemic responses to tourniquet release in children. Anesth Analg 1986; 65: 865-72.

20 Patel JA, Choi C, Gluffrida JG. Changes in end tidal $\mathrm{CO}_{2}$ and arterial blood gas levels after release of tourniquet. South Med J 1987; 80: 213-6.

21 Serjeant $G R$, Serjeant $B R$, Milner PF. The irreversibly sickled cell; a determinant of haemolysis in sickle cell anaemia. Br J Haematol, 1969; 17: 527-33.

22 Serjeant GR. Sickle Cell Disease, $1^{\text {st }}$ ed. New York: Oxford University Press, 1985; 50-1. 